\title{
REGIONÁLIS TAGOZÓDÁS SZLOVÁKIÁBAN
}

\author{
(Regional Articulation of Slovakia)
}

\section{KOVÁCS ERVIN}

\section{Bevezetö}

A hajdan volt európai szocialista országokat, a külön kategóriaként kezelt Szovjetuniót figyelmen kívül hagyva, szokásos volt két nagyobb, egy északi „,fejlett” és egy déli „elmaradott” csoportba sorolni. Az északi csoportba az NDK, Lengyelország, Csehszlovákia és Magyarország tartozott. Mára ezek az országok a politikaiés a társadalomföldrajzban egyaránt előszeretettel vizsgált területek, hiszen politikai rendszerük alapjaiban megváltozott, részben állami kereteik is módosultak, $\mathrm{s}$ fejlettségi pályájuk is új, átalakuló irányt vett. Az ezredfordulóra e hajdani „négyesfogatból” leginkább megkésettnek Szlovákia minősül, bár pályája alapjaiban azonos irányt jelez, mint társaié. Az azonosság egyik fontos jegye a felerősödött regionális tagoltság. Tanulmányunkban ennek föbb dimenzióit mutatjuk be Szlovákia esetében.

\section{Regionális átalakulás a transzformáció időszakában}

A rendszerváltás óta a társadalom Szlovákiában is alapvető változásokon ment keresztül. Az ország területi szerkezete és térbeli társadalmi-gazdasági folyamatai is követték a változásokat. Területi, települési szinten a hatások látványosak voltak, hiszen a válságtérségekben tömegesen szűntek meg a munkahelyek, egy-egy ágazat összeomlásával térségek, települések kerültek nehéz helyzetbe, vagy a korábbi természetes kapcsolatok (pl. ingázási irányok, vonzáskörzetek) rendeződtek át egyik napról a másikra. A modernizáció nehézségeit az emberek, a háztartások, a gazdasági szereplök, de a politikai-társadalmi szereplök is a lakóhelyükön, azaz egy meghatározott településen, térségükben élték át. Így az ismeretek, a tapasztalatok mindig egy-egy jól elhatárolható területi egységhez köthetők, ami a változások egyediségét éppen úgy képviseli, mint annak törvényszerüségeit.

Az 1989 utáni transzformáció még jobban kiemelte az így keletkezett különbségeket. A legfejletlenebb régiókban nött legintenzívebben a munkanélküliség, és ezek a járások társadalmilag és gazdaságilag még jobban visszaestek.

A déli, keleti és északi határvidék járásain kívül rossz gazdasági helyzetbe kerültek a konverzióval sújtott, a mezögazdasági termelésen alapuló és a nem perspektívikus termelési szerkezettel rendelkező járások is.

Megjelent az országban a külföldi tőke, mely nem volt olyan nagy hatással a térszerkezet átrendezödésére mint a környezö országokban, mivel azokhoz képest 
viszonylag kevés külföldi tőke érkezett, és az is szinte kétharmad részben Pozsonyba irányult. Egyes járások viszonylag jó pozícióját egy cégbe fektetett tőke okozza. Pozsony kedvezö helyzete a befektetett tőke szempontjából a jó közlekedési kapcsolatokban, gyors elérhetöségében, az ipari termelési tapasztalatokban és munkakultúrában, infrastrukturális felszereltségben (telefon, közlekedés, közmüvek), az alkalmazkodási stratégiák kialakításában és alkalmazásában keresendők.

Az önkormányzati rendszer létrejötte nemcsak a helyi közösségek önmagukra találásában volt döntö jelentőségü, hanem abban is, hogy egy új gazdasági szereplő jelent meg. Az önkormányzat vagyonnal rendelkezik, rendszeres bevételre tesz szert, az intézményeit múködteti, munkahelyet biztosít, hatást gyakorol a lokálisregionális piacra (helyi beszerzések, foglalkoztatás, jövedelem), illetve szerepet vállal a helyi gazdaságfejlesztésben, annak bizonyos feltételeinek alakításában (helyi adók, kínálatorientált helyi gazdaságfejlesztés). Az átmenetben az önkormányzati szektor még a szerepeit keresi, mivel nem került tisztázásra az állami és helyi feladatok közötti egyértelmủ feladatmegosztás.

Az új területi-közigazgatási felosztással megnövekedett a járások száma, ami azt eredményezte, hogy az ország térszerkezete még megosztottabbá vált, miközben nôtt a szakadék a legrosszabb és a legjobb helyzetủ régiók között.

Az átalakuló gazdaság térszerkezetét vizsgálva teljesen új szempontokat kell figyelembe vennünk, ha a jellemző folyamatokat akarjuk bemutatni. A vizsgálódásba a mai idôszak jellegadó, új struktúrát formáló folyamatainak elemzését kell bevonni.

Ez mindenekelött azt jelenti, hogy azt kell vizsgálnunk, miként oszlanak el, tagolódnak és kombinálódnak a térben az időszak válságjegyei (munkanélküliség, jövedelemhelyzet), illetve dinamikahordozó elemei (vállalkozási aktivitás, külföldi tőkevonzás).

\section{A fejlettségi térszerkezet}

E tényezők egyenként is vizsgálhatók, összevont értékelésükre a területi elemzésekben széleskörüen elterjedt matematikai-statisztikai módszer, a faktoranalizis alkalmas. Szlovákia térbeli társadalmi-gazdasági tagoltságát e módszerrel az 1996 júliusától érvényes új közigazgatási beosztás térbeli kereteiben mutatjuk be, 79 járás szintjén. A vizsgálatból kihagytuk a Pozsony I., II., III. járásokat, melyek minden szempontból kiemelkednek a többi járás közül, ezért beszámításuk jelentős mértékben torzította volna a faktoranalízis eredményét.

A faktoranalízishez 8 mutatót használtunk fel ${ }^{1}$ :

- 1 före jutó GDP (ezer SK-ban)

- munkanélküliségi ráta (\%-ban)

- 1 före jutó befektetések (ezer SK-ban)

- ezer före jutó gazdasági társaságok száma

- ezer före jutó magánvállalkozók száma

- vegyesvállalatok aránya (\%-ban) 
- gázhálózatba bekapcsolt lakások aránya (\%-ban)

- szennyvízcsatorna-hálózatba bekapcsolt lakások aránya (\%-ban)

A faktoranalízis egy (,fejlettségi”) faktort jelölt ki, melynek sajátértéke 4,75. A faktor az alapváltozók által tartalmazott információ 59\%-át tömöríti (1. táblázat).

\section{TÁBLÁZAT}

A faktoranalizis komponens mátrixa

(Correlation Matrix of the Factor Analysis)

\begin{tabular}{lc}
\hline \multicolumn{1}{c}{$\quad$ Alapváltozók } & Faktor \\
\hline GDP/fó & 0,75440 \\
munkanélkúliségi ráta & $-0,62774$ \\
1 fóre jutó befektetések & 0,70501 \\
ezer fởre jutó gazdasági társaságok száma & 0,86857 \\
ezer före jutó magánvállalkozók száma & 0,79524 \\
vegyesvállalatok aránya & 0,89027 \\
gázhálózatba bekapcsolt lakások aránya & 0,80111 \\
szennyvízcsatorna-hálózatba bekapcsolt lakások aránya & 0,69006 \\
\hline
\end{tabular}

Forrás: Saját számítás.

A vizsgálat szerint a térségek élmezőnyébe a Pozsonyi járások (Pozsony I., II., III. nélkül) a Kassa I., II., III., IV. járások, a Besztercebányai, Szenci, Zsolnai, Trencséni, Zólyomi járások, vagyis a nagyvárosok járásai és a nagyobb várossal rendelkező járások kerültek. A legrosszabb helyzetủek szinte kivétel nélkül a keletszlovákiai járások (2. táblázat). (A kutatás során - azonos módszerrel - vizsgáltuk a térségi fejlettséget az 1996 előtti közigazgatási beosztás szerint is. A két elemzés lényegében ugyanazt a regionális fejlettségi sémát hozta felszínre. Ez azzal a tanulsággal jár, hogy a politikai szempontból sokat vitatott közigazgatási reform a térségi fejlettségi tagoltság képében és megítélésünk szempontjából igazából nem hozott új helyzetet létre, megmaradt a kelet-nyugati lejtés a járások között, a keleten lévő új járások kivétel nélkül a hátrányos helyzetúek közé sorolhatók. Itt csupán Kassa emelkedik ki szigetként a hátrányos helyzetủ járások tengeréből.)

Az ország térszerkezetéről a komplex értékelés alapján elmondható, hogy egy stabilabb helyzetü nyugati illetve egy válságterhes keleti országrészre tagolódik. Ugyanakkor eléggé mozaikszerü képet kapunk, mivel a nyugati részeken is akadnak válságos térségek (Nyugat-Szlovákia déli része), illetve a keleti részben találhatók a változásból profitáló területek (Kassa, Eperjes) (1.ábra).

$\mathrm{Az}$ ország egész területén szinte minden nagyváros (Pozsony, Zsolna, Besztercebánya, Kassa, Trencsén) fejlődési pólusnak számít, ezek kisugárzása azonban alig terjed túl a közigazgatási határon. A fövárosról elmondható, hogy elkülönül az ország többi részétöl, ami igaz volt a régi járási felosztás szerint is, és nem változott az új területi közigazgatási felosztás szerint sem.

A marginalizálódott határ menti térségek felzárkózásában komoly szerepe lehet a határon átnyúló kapesolatok fejlesztésének. Ezért Szlovákia és az egész térség érdeke, hogy a térség gazdaságai stabilizálódjanak, és valódi gazdasági kapcsolatok alakuljanak ki közöttük. 
Kovács Ervin : Regionális tagozódás Szlovákiában

Tér és Társadalom 14. évf. 2000/2-3. 239-244. p.

\section{TÁBLÁZAT}

A fejlettségi faktor alapján összeállított járási rangsor

(Hierarchy of Districts Based on the Advanced Factor)

\begin{tabular}{lllc}
\hline \multicolumn{1}{c}{ Járás } & Faktor & \multicolumn{1}{c}{ Járás } & Faktor \\
\hline Pozsony IV. & 3,74474 & Rózsahegy & $-0,26230$ \\
Kassa I. & 3,57660 & Losonc & $-0,26921$ \\
Besztercebánya & 2,41915 & Igló & $-0,29661$ \\
Kassa II. & 2,28185 & Aranyosmarót & $-0,31999$ \\
Pozsony V. & 2,02480 & Nagytapolcsány & $-0,32983$ \\
Kassa IV. & 1,70157 & Érsekújvár & $-0,35996$ \\
Szenc & 1,07828 & Stubnyafürdö & $-0,37077$ \\
Zsolna & 1,02880 & Rozsnyó & $-0,40045$ \\
Trencsén & 0,94619 & Bán & $-0,42131$ \\
Zólyom & 0,86249 & Léva & $-0,43348$ \\
Bazin & 0,84551 & Zsarnóca & $-0,44758$ \\
Poprád & 0,79231 & Homonna & $-0,46404$ \\
Pöstyén & 0,76027 & Nagymihály & $-0,48865$ \\
Kassa III. & 0,63536 & Nagybicse & $-0,56000$ \\
Szakolca & 0,60089 & Gyetva & $-0,56321$ \\
Privigye & 0,45170 & Bártfa & $-0,60190$ \\
Dunaszerdahely & 0,43388 & Kiszucaújhely & $-0,60286$ \\
Nyitra & 0,41537 & Turdossin & $-0,64998$ \\
Vágbeszterce & 0,41440 & Ólubló & $-0,73356$ \\
Garamszentkereszt & 0,41265 & Rimaszombat & $-0,73710$ \\
Malacka & 0,35071 & Nagykürtös & $-0,75498$ \\
Illava & 0,33193 & Korpona & $-0,78761$ \\
Túrócszentmárton & 0,30617 & Csaca & $-0,79052$ \\
Komárom & 0,28197 & Kassa-kỏmyéke & $-0,84098$ \\
Nagyszombat & 0,26685 & Felsóvízköz & $-0,84804$ \\
Puhó & 0,23951 & Löcse & $-0,85756$ \\
Galánta & 0,23016 & Sztropkó & $-0,86118$ \\
Vágújhely & 0,15080 & Késmárk & $-0,87956$ \\
Alsókubin & 0,07396 & Töketerebes & $-0,91361$ \\
Liptószentmiklós & 0,06902 & Szinna & $-0,93249$ \\
Vágsellye & $-0,04426$ & Námesztó & $-0,93806$ \\
Selmecbánya & $-0,06285$ & Gölnicbánya & $-0,96863$ \\
Szenice & $-0,11176$ & Nagyröce & $-0,97179$ \\
Eperjes & $-0,11739$ & Varannó & $-1,02999$ \\
Simony & $-0,16832$ & Poltár & $-1,11900$ \\
Galgóc & $-0,17094$ & Mezólaborc & $-1,19979$ \\
Miava & $-0,19307$ & Kisszeben & $-1,22994$ \\
Breznóbánya & $-0,24538$ & Szobránc & $-1,37743$ \\
\hline & & & \\
Foras & & & \\
\hline
\end{tabular}

Forrás: Saját számítás. 
Kovács Ervin : Regionális tagozódás Szlovákiában

Tér és Társadalom 14. évf. 2000/2-3. 239-244. p.

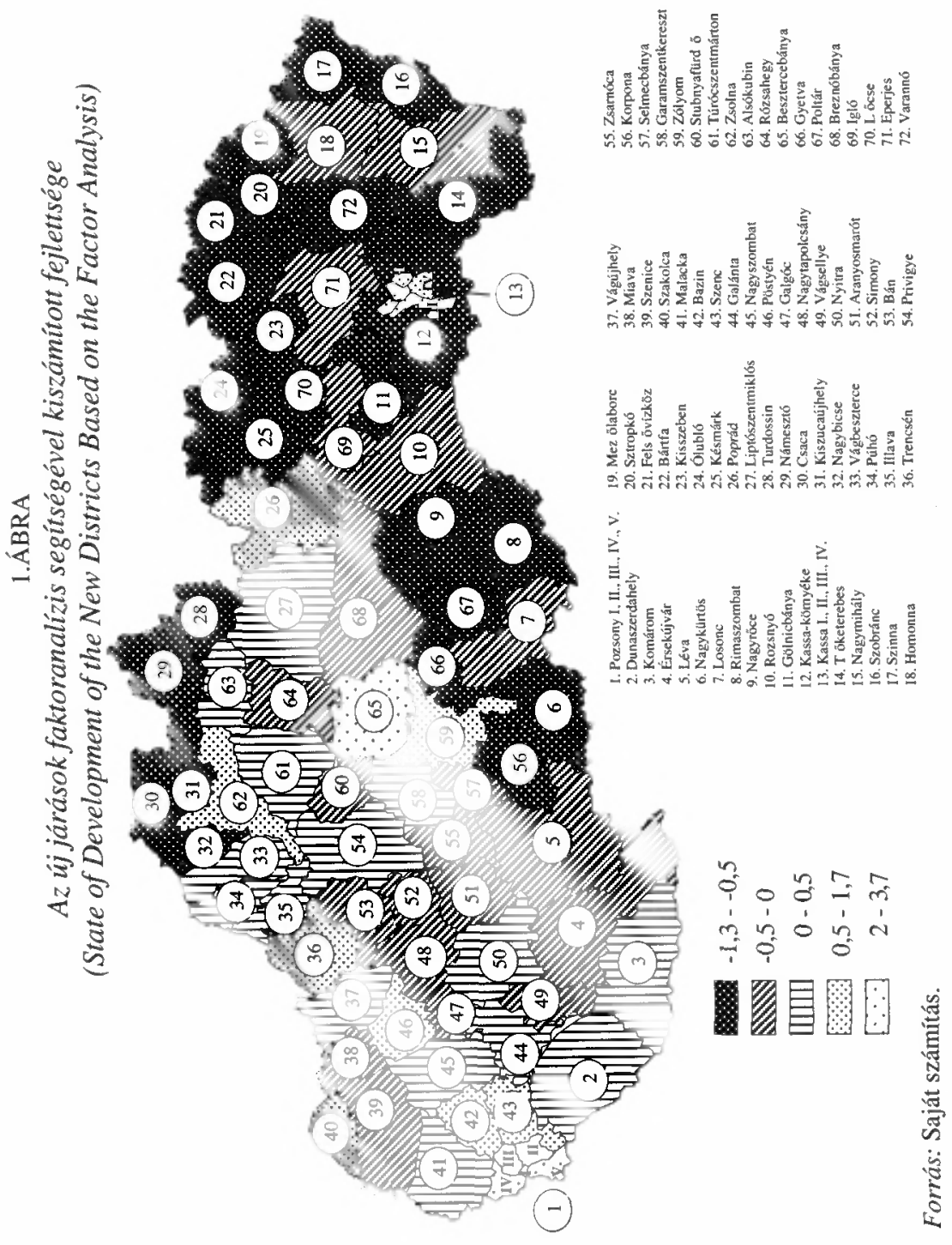




\section{Jegyzet}

${ }^{1}$ A mutatók forrása: Szlovák Köztársaság Statisztikai Hivatala; Szlovák Köztársaság Gazdasági Minisztériuma. A mutatók az 1997-es évre vonatkoznak.

\section{Irodalom}

Buchta, S. (1998) OECD: Regionalizácia a trh práce. - Hospodárske noviny. 8. Júna.

Kárász, P.-Rencko, J.-Pauhofová, V. (1995) Ekonomický potenciál regiónov Slovenska z aspektu rozvojových možnosti. Bratislava, Nadácia Friedricha Eberta. Prognostický Ústav SAV.

Korec, P.-Lavko, V.-Tolmáci, L.-Zubrický, G. (1997) Kraje a okresy Slovenska. - Nové administratívne clenenie. Q 111. Bratislava.

Krivý, V. (1997) Regióny. Slovensko 1996. Sührnná správa o stave spolocnosti a trendoch na rok 1997. - Bútora, M (ed.), Bratislava. Inštitút pre verejné otázky.

Krnác, P.-Miculík, M. (1998) Nezamestnanost v regiónoch Slovenskej Republiky. - Hospodárske noviny. 3. Apríla.

Nižnanský, V. (1998) Sluby a realita. Slovenská ekonomika 1995-1998. Bratislava, M. E. S. A. 10.

Sotník, A. (1999) Regionálne križovatky Slovenska. - Profit. 9. 23. februára

\section{REGIONAL ARTICULATION OF SLOVAKIA}

\section{ERVIN KOVÁCS}

Since the change of regime the society also passed through fundamental changes in Slovakia. Spatial structure and spatial socio-economic process followed the changes. The effects were spectacular in the level of regions and settlements as employment was radically decreased in crisis regions, settlements and whole regions experienced difficult situations with the collapse of certain industries, or former natural relationships (e.g. direction of commute, gravitation areas) was rearranged from day to day.

Based on the factor analysis shown in the study it can be stated that Slovakia is divided into a more stable western and a depression eastern part of the country. On the other hand we are given a fairly mosaic picture because there are crisis areas in the western parts (southern part of Western Slovakia) and there are areas in the eastern part that profited from the changes (Kassa, Eperjes). 